\title{
PROPOSALS TO CONSERVE OR REJECT NAMES
}

Edited by John McNeill, Scott A. Redhead \& John H. Wiersema

\section{(2479) Proposal to conserve the name Marattia kaulfussii (Eupodium kaulfussii) against M. raddiana (Marattiaceae)}

\author{
Marcelo Daniel Arana, ${ }^{1}$ Maarten J.M. Christenhusz ${ }^{2}$ \& Monica Ponce $^{3}$ \\ 1 Orientación Botánica II, Departamento de Ciencias Naturales, Facultad de Ciencias Exactas, Físico-Químicas y Naturales, \\ Universidad Nacional de Rio Cuarto, Ruta $36 \mathrm{~km}$ 601, X5804ZAB Río Cuarto, Córdoba, Argentina \\ 2 Conservation Department, Royal Botanic Gardens, Kew, Richmond TW9 3DS, Surrey, U.K. \\ 3 Instituto de Botánica Darwinion (ANCEFN-CONICET), Labardén 200, Casilla de Correo 22, B1642HYD San Isidro, Buenos Aires, 10 \\ Argentina
}

Author for correspondence: Marcelo Daniel Arana,marana@exa.unrc.edu.ar

DOI https://doi.org/10.12705/656.

(2479) Marattia kaulfussii J. Sm. ex Hook., Gen. Fil.: ad t. 26. 1839, nom. cons. prop. Typus: Brazil, 1816, Cunningham (BM barcode BM000785783!).

(=) Marattia raddiana Schott, Gen. Fil. 3: t. [5]. Jan-Mai 1835, nom. rej. prop.

Lectotypus (vide Christenhusz in Kew Bull 65: 116. 2010): Brazil, Rio de Janeiro, Corcovado, Angra dos Reis, Água da Serra, anno 1818, Pohl, Herb. Schott No. 3870 (W!; isolectotypus: PRC!).

The traditional genus Marattia Sw. was found to be polyphyletic due to the phylogenetic position of Angiopteris Hoffm. (Murdock in

25 Amer. J. Bot. 95: 626-641. 2008, in Taxon 57: 737-755. 2008) and hence the genus Eupodium J. Sm. (in J. Bot. (Hooker) 4: 190. Sep 1841) is now recognised as distinct, restricted to the Neotropics and including three species. Morphologically it is characterised in Marattiaceae by only having one frond at a time (occasionally two), bearing awns

30 along the veins, and having stalked synangia. Eupodium kaulfussii (J. Sm. ex Hook.) Hook. (Gen. Fil.: ad t. 118. 1842) is the original type of the generic name (vide Hooker, 1.c. 1842; Presl, Suppl. Tent. Pterid.: 16-17. 1845; Christenhusz, 1.c.: 115-121).

Regarding the typification of Marattia kaulfussii, the protologue 35 states: "M. Kaulfussii, J. Smith, mst. (pinnulis oblongo-ovatis pinnatifidis lobis bi-tridentatis, soris stipitatis ! - M. alata, Raddi, Fil. Bras. p. 74. t. 83. 84. et in Herb, nostr. non Sm." So, in addition to the specimen in (presumably) Hooker's herbarium, two illustrations in Raddi, Pl. Bras. Nov. Gen. 1825, are cited and so there is not a 40 holotype as some have supposed. Tryon \& Stolze (in Fieldiana, Bot., n.s. 20: 15. 1989) cited as type of Marattia kaulfussii "Brazil, 1816, Cunningham s.n. (holotype, BM!; photo, F!)". Their use of "holotype" can be treated as an error to be corrected to lectotype under Art. 9.9 of the ICN (McNeill \& al. in Regnum Veg. 154. 2012) and, because this was prior to 2001, when explicit designation became mandatory, it is an effective lectotype selection under Art. 7.10.
During a study of Marattiaceae for the Flora Argentina project 45 (www.floraargentina.edu.ar), we noticed that there is an earlier name at species rank for this neotropical fern from southern Brazil and northeastern Argentina, widely and commonly known as Eupodium kaufussii. The name Marattia raddiana Schott (1.c.) was published four years before Hooker published Marattia kaulfussii Sm. ex Hook. 50 (Hooker, 1.c. 1839), but the name was never widely applied - although treated as Gymnotheca raddiana (Schott) C. Presl (Suppl. Tent. Pterid.: 13. 1845) - and was only lectotypified in 2010 (Christenhusz, 1.c.: 116).

The only paper that rightly considered the priority of Marattia raddiana over M. kaulfussii is that of Christenhusz (1.c.: 116). But 55 since Eupodium kaulfussii or its basionym M. kaulfussii) has been applied in various treatments of South American Marattiaceae (e.g., Fée, Crypt. Vasc. Brésil: 214-215. 1869; Sodiro, Crypt. Vasc. Quit. 554-555. 1893; Lavalle in Darwiniana 41: 61-86. 2003; Murdock in Taxon 57: 737-755. 2008; Christenhusz, 1.c.: 115-121; Jørgensen \& al. in 60 Monogr. Syst. Bot. Missouri Bot. Gard. 127: 128. 2014), and in addition indicates the type of Eupodium, a name change for the species would be undesirable, causing a disadvantageous nomenclatural change. the prevention of which is the purpose of ICN Art. 14 (McNeill \& al., 1.c.). Unless this proposal is accepted, the epithet raddiana will need 65 to be combined under Eupodium and this will become the correct name of what is universally known as E. kaulfussii. Conservation of M. kaulfussii against M. raddiana is therefore seen as the best solution in the interest of nomenclatural stability.

\section{Acknowledgements}

We thank Dr. Manuel Belgrano and Dr. Fernando Zuloaga (SI) for advice concerning the names here considered and Dr. Jefferson Prado (SP), Dr. John Wiersema and Dr. John McNeill for their helpful comments. 